\title{
Effects of Different Disinfectants on Blue Mussel (Mytilus edulis L.) Embryo
}

\author{
Floriefe Gonzaga Torino \\ Assistant Professor IV, College of Fisheries, Mindanao State University- Buug Campus \\ Buug, Zamboanga Sibugay, 7009, Philippines
}

\begin{abstract}
Occurrence of diseases caused by bacteria during larval culture is still one of the major constraints in aquaculture. Understanding the host-microbe interactions is certainly relevant to develop disease control systems for the aquaculture industry. Therefore, obtaining test animals free from microorganisms (germfree or axenic) is necessary, as the presence of naturally occurring microorganisms in the host may lead to false conclusions. The aim of this study is to obtain axenic blue mussel (Mytilus edulis) embryo using different disinfectants. The efficacy of chemicals in reducing the bacterial load associated with mussel eggs and embryos is tested, as well as the resistance of the eggs to these chemicals. For that purpose, fertilized eggs are exposed to different chemicals at different concentrations. The disinfectants tested include hydrogen peroxide, chlorhexidine, and Sanocare HC. All disinfectants are found to be detrimental for the mussel embryo.
\end{abstract}

Keywords:- Mytilus edulis L.; Blue Mussel; broodstock mussels; Axenic; Germ Free; Bacteria Free; Sterile; Disinfectants.

\section{INTRODUCTION}

Aquaculture production is expected to play a crucial role in meeting the growing demand for fishery products since capture fisheries have markedly stagnated. Currently, it is the fastest growing sector in the food production industry with an average yearly growth rate of more than six percent over the past two decades [14]. In 2010, onethird of the world's farmed fish are coming from bivalve production [25]. Bivalve molluscs are important food commodity in the world. Natural population cannot meet the increasing demand due to over-exploitation, which led to development of hatcheries [3]. Nevertheless, mollusc aquaculture growth and sustainability are still hampered by the occurrence of diseases, severely impacting socioeconomic development [12]. Various methods have already been developed to control proliferation of pathogens and to maintain a healthy microbial environment in aquaculture systems. Among these are the use of probionts, immunostimulants, vaccines, quorum sensing analysis and antimicrobial peptides [41], [68], [40], [46]. However, the implementation of these alternative techniques should be based on thorough understanding of the mechanisms involved and the putative consequences [46].
It is certainly relevant to have a better understanding on the host-microbe interactions to develop effective solutions of disease control for the aquaculture industry [44]. A powerful tool to study these host-microbial relationships is to define the animal functioning in the absence of all micro-organisms (under germ-free or gnotobiotic conditions) and then evaluate the effects of adding a single or defined populations of microbes or certain compounds [34]. This allows determination of the effects of the tested microbes on the target organisms without interference from unwanted microbial contaminants [21]. Moreover, axenic animals provide a direct means to study the host's reaction to a single species of a pathogenic or parasitic agent [20]. Germ-free culture of animals has also been helpful in defining the nutrient requirements of the organism [54].

The aim of this study is to determine the effects of different disinfectants on the Blue Mussel (Mytilus edulis) embryo. To date, few studies are performed with gnotobiotic aquatic animals. This is the first study that attempts to generate bacteria-free mussel larvae (M. edulis) and will therefore provide baseline information for future research.

\section{MATERIALS AND METHODS}

\section{$>$ Obtaining Mussel Embryo}

Adult mussels, Mytilus edulis were obtained from the hatchery Roem van Yerseke, The Netherlands. They were thoroughly cleaned and stocked dry at $4^{\circ} \mathrm{C}$. Thermal shock technique was then employed to induce the mussels to spawn by submerging them first in warm filtered autoclaved seawater (FASW) at temperatures between 18 to $25^{\circ} \mathrm{C}$ followed by a cold shock treatment at temperatures between 5 to $10^{\circ} \mathrm{C}$. The male and female mussels that started spawning were placed separately in a sterile plastic beaker filled with FASW in order to collect the gametes separately (Figure 1). The adult mussels were removed from their respective spawning beakers when adequate amount of gametes were released. All the eggs were pooled in a one-litre sterile beaker which was topped-up with FASW till one litre. Sperm cells were then added to reach an approximate sperm to egg ratio of 10:1. After fertilization (15 minutes), the eggs were sieved $(30 \mu \mathrm{m})$ and washed with FASW to remove the excess of sperm. All manipulations were carried out under a laminar flow hood. Materials used were autoclaved for 20 minutes at $121^{\circ} \mathrm{C}$ and 15 psi. 


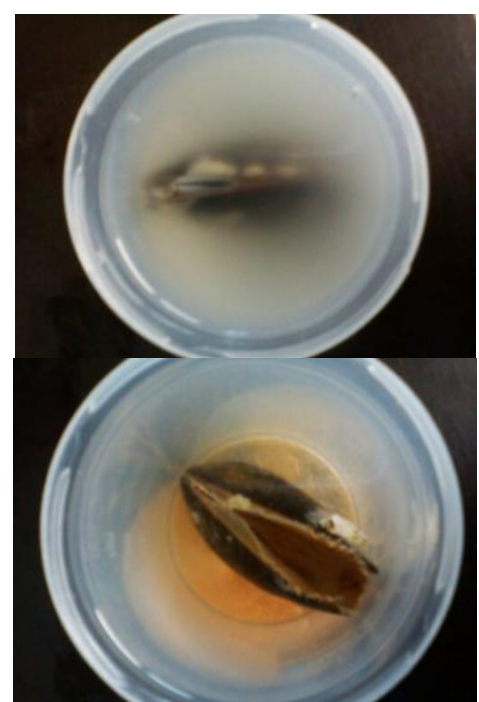

Fig 1:- Female (left) and Male (right) Mussels Spawning.

\section{Checking Axenity}

Bacterial contamination was checked by plating $100 \mu \mathrm{l}$ of undiluted culture medium on marine agar (Difco ${ }^{\mathrm{TM}}$ ) plates. Serial dilutions were not done for plating as it was not necessary to count the colonies. Plates were prepared by suspending $55.1 \mathrm{~g}$ of marine agar $\left(\mathrm{Difco}^{\mathrm{TM}}\right)$ in one litre of demineralised water. The solution was autoclaved for 20 minutes at $121^{\circ} \mathrm{C}$ and 15 psi. Pouring of the solution in the Petri plates was done under a laminar flow hood.

\section{$>$ Checking Larval Survival}

Larval survival was checked by staining the larvae with lugol solution inside the culture recipient and then concentrating the larvae by carefully removing the top layer of the water in the culture medium, after the larvae have sunk to the bottom. Concentrated larvae were transferred to 24-micro well plates and placed under an inverted microscope for observation. If quantitative data were needed, the live/dead ratio was counted of exactly 100 larvae. Live/good larvae were D-shaped larvae. Trochophore larvae (ciliated embryo) were also considered live larvae with delayed development. Empty shells and undeveloped eggs were considered dead.

\section{> Developing a Sterile Culture Procedure for Mussel Embryo Using Different Disinfectants.}

Different experiments were conducted in order to obtain sterile mussel embryo. The efficacy of chemicals in reducing the bacterial load on the mussel eggs and embryos were tested, as well as the resistance of the eggs to these chemicals. The fertilized eggs were exposed to different chemicals at different concentrations and time exposures, and were incubated in sterile plastic vials at densities 20-50 eggs $\mathrm{ml}^{-1}$ (Figure 2) in $10 \mathrm{ml}$ of FASW without aeration or mechanical shaking. Temperature was maintained at $17^{\circ} \mathrm{C}$ for all treatments. Axenity, survival and development of mussel larvae were monitored. All treatments with the eggs were replicated thrice and manipulations were done under a laminar flow.
ISSN No:-2456-2165

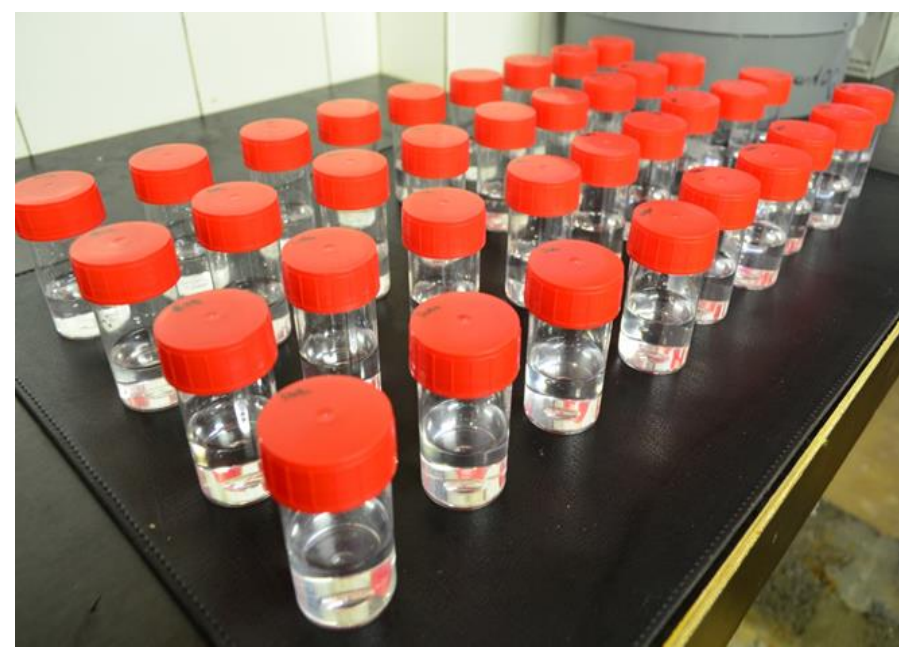

Fig 2:- Vials for incubation of fertilized eggs.

In Experiment 1, the fertilized eggs were incubated for 48 hours in sterile plastic vials with the addition of Sanocare HC in the following concentrations:

Treatment 1 - Sanocare $\mathrm{HC}-10 \mu \mathrm{g} \mathrm{ml}^{-1}$ Treatment 2 - Sanocare $\mathrm{HC}-50 \mu \mathrm{g} \mathrm{ml}^{-1}$ Treatment 3 - Sanocare HC - $150 \mu \mathrm{g} \mathrm{ml}^{-1}$ Treatment 4 - Sanocare HC - 200 $\mathrm{g} \mathrm{ml}^{-1}$ Treatment 5 - control

A stock solution of Sanocare HC $\left(10,000 \mu \mathrm{g} \mathrm{ml}^{-1}\right.$ was prepared by mixing $10 \mathrm{~g}$ of Sanocare $\mathrm{HC}$ in one litre of FASW with electric mixer to obtain an emulsion (100x more concentrated).

In Experiment 2, fertilized eggs were exposed to chlorhexidine in demineralised water (since chlorhexidine hardly dissolves in seawater), for 1 minute at concentrations of:

Treatment 1 - Chlorhexidine - $100 \mu \mathrm{g} \mathrm{ml}^{-1}$

Treatment 2 - Chlorhexidine $-250 \mu \mathrm{g} \mathrm{ml}^{-1}$

Treatment 3 - Chlorhexidine - 500 $\mu \mathrm{g} \mathrm{ml}^{-1}$

Treatment 4 - control 1 - demineralised water

Treatment 5 - control 2 - FASW

Two controls were made to check whether chlorhexidine or the freshwater has an effect on the eggs: for Control 1, eggs exposed for one minute in demineralised water and for Control 2, eggs exposed for one minute in FASW, to check if the handling has a negative effect on the embryos. Five beakers were prepared containing different concentrations of chlorhexidine and the controls. Different concentrations of chlorhexidine (100, 250 and $500 \mu \mathrm{g} \mathrm{ml}^{-1}$ ) were prepared by adding 100,250 and $500 \mu \mathrm{g}$ of chlorhexidine to sterile beakers filled with one litre water to obtain the desired concentration. Exposure was done by submerging the sieve $(30 \mu \mathrm{m})$ containing the fertilized eggs in the beaker for one minute. The eggs were then rinsed with FASW and incubated for 72 hours in sterile plastic vials. 
Experiment 3, fertilized eggs were exposed to hydrogen peroxide $\left(\mathrm{H}_{2} \mathrm{O}_{2}\right)$ in seawater for 3 minutes at the following concentrations:

Treatment $1-\mathrm{H}_{2} \mathrm{O}_{2}-0.3 \%$

Treatment $2-\mathrm{H}_{2} \mathrm{O}_{2}-1.5 \%$

Treatment $3-\mathrm{H}_{2} \mathrm{O}_{2}-3 \%$

Treatment 4 - control

Exposure of the fertilized eggs with hydrogen peroxide was done according to the same procedure described in Experiment 2. The eggs were washed with FASW after exposure and then incubated in the plastic vials for 72 hours.

Axenity, survival and larval development were checked after 48 hours for Experiment 1 while in Experiments 2, and 3 after 72 hours post fertilization. Schematic diagram of the experiments is presented in Figure 3.

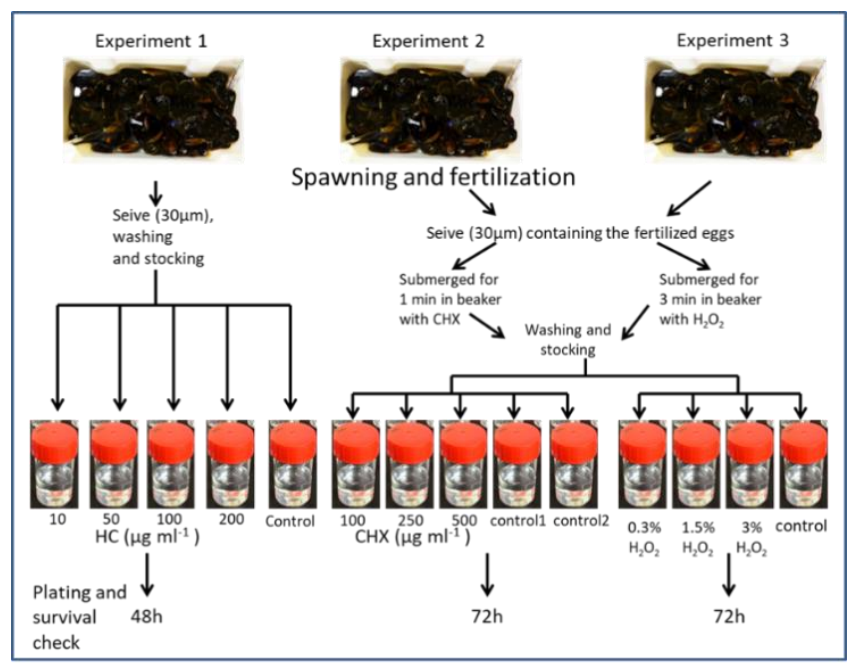

$\mathrm{HC}$ - Sanocare HC; $\mathrm{CHX}$ - Chlorhexidine; $\mathrm{H}_{2} \mathrm{O}_{2}$ Hydrogen peroxide

Fig 3:- Schematic diagram of the three experiments

\section{RESULTS AND DISCUSSION}

\section{$>$ Effects of Different Disinfectants on Mussel embryo}

Sanocare HC® is a product developed by INVE Aquaculture that reduces the development and transfer of putative pathogens associated with live food culture. It is a self-emulsifying product that ensures maximum bacterial suppression during Artemia hatching. Different concentrations of Sanocare HC were tested in Experiment 1. Results revealed bacterial contamination at all concentrations, going from 10 to $200 \mu \mathrm{g} \mathrm{ml}^{-1}$ (Table 1). After 48 hours of exposure, no D-larvae were observed in the control treatment, treatments $1\left(10 \mu \mathrm{g} \mathrm{ml} \mathrm{ml}^{-1}\right)$ and treatment $2\left(50 \mu \mathrm{g} \mathrm{ml}^{-1}\right)$. This is due to the fact that it was still too early for the larvae to reach this development stage. Higher concentrations of Sanocare HC, treatments 3 $\left(100 \mu \mathrm{gml}^{-1}\right)$ and $4\left(200 \mu \mathrm{g} \mathrm{ml}^{-1}\right)$ were found to be lethal since the eggs had not developed into trochophore larvae. In the study of [69], Sanocare HC significantly reduced the Vibrio loads in Artemia hatching water without affecting the embryo. Artemia cysts have a chorion that protects the embryo from the chemicals. In contrast, mussel embryos only possess a vitelline coat of $0.5-1.0 \mu \mathrm{m}$ thick [8] which makes them very vulnerable to chemicals.

\begin{tabular}{|c|c|c|c|}
\hline Experiment & Treatment & Axenity & $\begin{array}{c}\text { Development/Survival } \\
\text { (48h after } \\
\text { fertilization) }\end{array}$ \\
\hline 1 & $\begin{array}{c}1(10 \mu \mathrm{g} \\
\left.\mathrm{ml}^{-1} \mathrm{HC}\right)\end{array}$ & - & Trochophore \\
& $\begin{array}{c}2(50 \mu \mathrm{g} \\
\left.\mathrm{ml}^{-1} \mathrm{HC}\right)\end{array}$ & - & $\begin{array}{c}\text { Trochophore, } \\
\text { Undeveloped eggs }\end{array}$ \\
\hline & $\begin{array}{c}3(100 \mu \mathrm{g} \\
\left.\mathrm{ml}^{-1} \mathrm{HC}\right)\end{array}$ & - & Undeveloped eggs \\
& $\begin{array}{c}4(200 \mu \mathrm{g} \\
\left.\mathrm{ml}^{-1} \mathrm{HC}\right)\end{array}$ & - & Undeveloped eggs \\
\hline & $5(\mathrm{Control})$ & - & Trochophore \\
\hline
\end{tabular}

HC - Sanocare HC, (-) : Bacterial contamination, (+) : axenic

Table 1:- The effects of different concentrations of Sanocare HC on mussel embryos

In Experiment 2, different concentrations of the disinfectant chlorhexidine were evaluated. As shown in Table 2, none of the concentrations did eliminate microbial contaminants. Larval survival and development was checked after 72 hours and D-larvae were observed in the treatment Control 2 (FASW). Total mortality was observed in all of the treatments even in the Control 1 (demineralised water). Chlorhexidine is one of the best and most widely used antiseptics. It is a strong base and is most stable in the form of its salt [29]. Dilutions of chlorhexidine were prepared by mixing in demineralised water since it precipitates in seawater. Exposure to a freshwater solution of chlorhexidine caused the eggs to burst because of osmosis. This in turn leads to leakage of nutrients into the water that would enhance microbial growth and deteriorate the water quality [21].

\begin{tabular}{|c|c|c|c|}
\hline Experiment & Treatment & Axenity & $\begin{array}{c}\text { Development/Survival } \\
\text { (72h after } \\
\text { fertilization) }\end{array}$ \\
\hline 2 & $\begin{array}{c}1(100 \mu \mathrm{g} \\
\left.\mathrm{ml}^{-1} \mathrm{CHX}\right)\end{array}$ & - & Total mortality \\
\hline & $\begin{array}{c}2(250 \mu \mathrm{g} \\
\left.\mathrm{ml}^{-1} \mathrm{CHX}\right)\end{array}$ & - & Total mortality \\
\hline & $\begin{array}{c}3(500 \mu \mathrm{g} \\
\left.\mathrm{ml}^{-1} \mathrm{CHX}\right)\end{array}$ & - & Total mortality \\
\hline & $\begin{array}{c}4(\mathrm{Control} \\
1)\end{array}$ & - & Total mortality \\
\hline & $\begin{array}{c}5(\mathrm{Control} \\
2)\end{array}$ & - & D larvae \\
\hline
\end{tabular}

CHX - Chlorhexidine, (-) - Bacterial contamination, (+) axenic

Table 2:- The effects of Different Concentrations of Chlorhexidine on Mussel Embryos 
Hydrogen peroxide is a highly reactive, strong oxidizing and bleaching agent [73]. It has long been used as a disinfectant for different species and life stages of fish against organisms that cause diseases such as external parasites, bacteria and fungi [73]. [21] obtained bacteriafree red drum (Sciaenops ocellatus L.) larvae by exposing the eggs to hydrogen peroxide $(3 \%)$ for five minutes. This disinfectant was used in Experiment 3 at different concentrations. Treatments $2(1.5 \%)$ and $3(3 \%)$ showed no evidence of bacterial contamination while treatment 1 $(0.3 \%)$ and treatment control had bacterial colonies growing on the plates (Table 3). The disinfectant however adversely affected the larval development causing total mortality. This is in contrast to the results of [21] where no adverse effects on the larval survival of red drum (Sciaenops ocellatus L.) were observed. However, when the disinfectant was tested on eggs of two other marine fishes (yellowtail snapper, Ocyurus chrysurus, and spotted seatrout, Cynoscion nebulosus Cuvier), the exposure to different concentrations showed differential toxicity [21].

\begin{tabular}{|c|c|c|c|}
\hline Experiment & Treatment & Axenity & $\begin{array}{c}\text { Development/Survival } \\
\text { (72h after } \\
\text { fertilization) }\end{array}$ \\
\hline 3 & $\begin{array}{c}1(0.3 \% \\
\left.\mathrm{H}_{2} \mathrm{O}_{2}\right)\end{array}$ & - & Total mortality \\
\hline & $\begin{array}{c}2(1.5 \% \\
\left.\mathrm{H}_{2} \mathrm{O}_{2}\right)\end{array}$ & + & Total mortality \\
\hline & $3(3 \%$ & + & Total mortality \\
& $\left.\mathrm{H}_{2} \mathrm{O}_{2}\right)$ & - & D larvae, empty shell \\
\hline & $4(\mathrm{Control})$ & - & \\
\hline
\end{tabular}

$\mathrm{H}_{2} \mathrm{O}_{2}-$ Hydrogen peroxide, (-) : Bacterial contamination, $(+)$ : axenic

Table 3:- The Effects of Different Concentrations of Hydrogen Peroxide on Mussel Embryos

\section{CONCLUSION}

All disinfectants (hydrogen peroxide, chlorhexidine and Sanocare HC) seriously damaged the embryos resulting in delayed development and high mortalities. Further research and verification are needed, such as finding disinfectants that are not harmful to the mussel embryos and use of antibiotics.

\section{REFERENCES}

[1]. Anguiano-Beltrán, C., Lizárraga-Partida, M. L., and Searcy-Bernal, R. (2004). Effect of Vibrio alginolyticus on larval survival of the blue mussel Mytilus galloprovincialis. Diseases of aquatic organisms, 59(2), 119-123. doi:10.3354/dao059119

[2]. Arzul, I., Renault, T., and Lipart, C. (2001). Experimental herpes-like viral infections in marine bivalves: demonstration of interspecies transmission. Diseases of aquatic organisms, 46(1), 1-6. Retrieved from http://archimer.ifremer.fr/doc/00000/819/
[3]. Avendaño, R. E., and Riquelme, C. E. (1999). Establishment of mixed-culture probiotics and microalgae as food for bivalve larvae. Aquaculture Research, 30(11-12), 893-900. doi:10.1046/j.1365$\underline{2109.1999 .00420 . \mathrm{x}}$

[4]. Baker, D. E. (1966). The commercial production of mice with a specified flora.National Cancer Institute monograph, 20, 161-166.

[5]. Baker, J. A., Ferguson, M. S., and TenBroeck, C. (1942). Growth of Platyfish (Platypoecilus maculatus) Free from Bacteria and Other Microorganisms. Proceedings of the Society for Experimental Biology and Medicine. Society for Experimental Biology and Medicine (New York, N.Y.), 51(1), 116-119. doi:10.3181/00379727-51-13854

[6]. Bayne, B. L. (1964). The Responses of the Larvae of Mytilus edulis L. to Light and to Gravity. Oikos, 15(1), 162. doi:10.2307/3564753

[7]. Bayne, B. L. (1965). Growth and the delay of metamorphosis of the larvae of Mytilus edulis L.. Ophelia, 2(1), 47.doi:10.1080/00785326.1965.10409596

[8]. Bayne, B. L. (1976). Marine mussels: their ecology and physiology. Cambridge University Press.

[9]. Bayne, B. L., Bubel, A., Gabott, P. A., Livingstone, D. R., Lowe, D. M., and Moore, M. N. (1982). Glycogen utilisation and gametogenesis in Mytilus edulis L.

[10]. Bayne, B. L., Holland, D. L., Moore, M. N., Lowe, D. M., and Widdows, J. (1978). Further studies on the effects of stress in the adult on the eggs of Mytilus edulis L. Journal of the Marine Biological Association of the United Kingdom, 58(04), 825-841. doi:10.1017/S0025315400056794

[11]. Berthe, F. (2004). Report about mollusc diseases. In: Alvarez-Pellitero P. (ed.), Barja, L. (ed.), Basurco, B. (ed.), Berthe, F (ed.), Toranzo A. E., (ed.). Mediterranean Aquaculture diagnostic laboratories. Zaragoza: CIHEAM. 33-48.

[12]. Berthe, F. (2005). Diseases in mollusc hatcheries and their paradox in health management. Presented at the Diseases in Asian Aquaculture. Retrieved from http://archimer.ifremer.fr/doc/00000/3289/

[13]. Bouchet, P., and Gofas, S. (2013). Mytilus edulis Linnaeus, 1758. World Register of Marine Species. Retrieved from http://www.marinespecies.org/aphia.php?p=taxdetails \&id=138228 on 2013-03-06

[14]. Brugère, C. D., and Ridler, N. B. (2004). Global aquaculture outlook in the next decades: an analysis of national aquaculture production forecasts to 2030. Rome: Food and Agriculture Organization of the United Nations. Retrieved from ftp://ftp.fao.org/docrep/fao/007/y5648e/y5648e0 $\underline{0 . p d f}$

[15]. Chernin, E. (1957). A Method of Securing Bacteriologically Sterile Snails (Australorbis glabratus). Experimental Biology and Medicine, 96(1), 204-210. doi:10.3181/00379727-96$\underline{23433}$ 
[16]. Coates, M. E. (1975). Gnotobiotic animals in research: their uses and limitations. Laboratory animals, 9(4), 275-282. Retrieved from http://lan.sagepub.com/content/9/4/275.full.pdf

[17]. Coates, M. E., and O’donoghue, P. N. (1967). Milk Allergy in Infant Germ-free Rabbits.Nature, 213(5073), 307-308. doi: $10.1038 / 213307 \mathrm{a} 0$

[18]. Delahaut, Vyshal. (2012). Development of a Challenge Test for the Blue Mussel, Mytilus edulis. Gent University, Gent, Belgium. Retrieved from http://lib.ugent.be/fulltxt/RUG01/001/894/276/RUG0 1-001894276_2012_0001_AC.pdf

[19]. Dierckens, K., Rekecki, A., Laureau, S., Sorgeloos, P., Boon, N., Van den Broeck, W., and Bossier, P. (2009). Development of a bacterial challenge test for gnotobiotic sea bass (Dicentrarchus labrax) larvae. Environmental microbiology, 11(2), 526-533. doi:10.1111/j.1462-2920.2008.01794.x

[20]. Douillet, P. (1998). Disinfection of rotifer cysts leading to bacteria-free populations. Journal of Experimental Marine Biology and Ecology,224(2), 183-192. doi:10.1016/S0022-0981(97)00200-1

[21]. Douillet, P. A., and Holt, G. J. (1994). Surface disinfection of red drum (Sciaenops ocellatus L.) eggs leading to bacteria-free larvae. Journal of Experimental Marine Biology and Ecology, 179(2), 253-266. doi:10.1016/0022-0981(94)90118-X

[22]. Elmolla, E. S., and Chaudhuri, M. (2010). Degradation of amoxicillin, ampicillin and cloxacillin antibiotics in aqueous solution by the UV/ZnO photocatalytic process. Journal of Hazardous Materials, 173(1-3), 445-449. doi:10.1016/j.jhazmat.2009.08.104

[23]. Elston, R., and Leibovitz, L. (1980). Pathogenesis of Experimental Vibriosis in Larval American Oysters, Crassostrea virginica.Canadian Journal of Fisheries and Aquatic Sciences, 37(6), 964-978. doi: 10.1139/f80-126

[24]. Erasmus, J. H., Cook, P. A., and Coyne, V. E. (1997). The role of bacteria in the digestion of seaweed by the abalone Haliotis midae. Aquaculture, 155(1-4), 377386. doi:10.1016/S0044-8486(97)00112-9

[25]. FAO (2012). Fishery Statistics of Cultured Aquatic Species Information Programme. Retrieved from http://www.fao.org/fishery/species/2688/en

[26]. FAO (2012). The State of World Fisheries and Aquaculture. Rome: Food and Agriculture Organization of the United Nations.

[27]. Faraji, R., Parsa, A., Torabi, B., and Withrow, T. (2006). Effects of kanamycin on the macromolecular composition of kanamycin sensitive Escherichia coli DH5 $\alpha$ strain. Journal of Experimental Microbiology and Immunology, 9, 31-38. Retrieved from http://www.microbiology.ubc.ca/sites/default/files/rol es/drupal ungrad/JEMI/9/9-31.pdf

[28]. Forberg, T., Arukwe, A., and Vadstein, O. (2011). A protocol and cultivation system for gnotobiotic Atlantic cod larvae (Gadus morhua L.) as a tool to study host microbe interactions. Aquaculture, 315(34), 222-227. doi:10.1016/j.aquaculture.2011.02.047
[29]. Foulkes, D. M. (1973). Some toxicological observations on chlorhexidine. Journal of periodontal research. Supplement, 12, 55-60.

[30]. Frank, J. A., Reich, C. I., Sharma, S., Weisbaum, J. S., Wilson, B. A., and Olsen, G. J. (2008). Critical Evaluation of Two Primers Commonly Used for Amplification of Bacterial 16S rRNA Genes. Applied and Environmental Microbiology, 74(8), 2461-2470. doi:10.1128/AEM.02272-07

[31]. Franklin, T. J., and Snow, G. A. (2005). Biochemistry and Molecular Biology of Antimicrobial Drug Action. Springer.

[32]. Galley, T. H., Batista, F. M., Braithwaite, R., King, J., and Beaumont, A. R. (2010). Optimisation of larval culture of the mussel Mytilus edulis (L.).Aquaculture International, 18(3), 315-325. doi:10.1007/s10499009-9245-7

[33]. Gee, L. L., and Sarles, W. B. (1942). The Disinfection of Trout Eggs Contaminated with Bacterium Salmonicida. Journal of Bacteriology, 44(1), 111$126 . \quad$ Retrieved from http://www.ncbi.nlm.nih.gov/pmc/articles/PMC37365 4/

[34]. Gordon, H. A., and Pesti, L. (1971). The gnotobiotic animal as a tool in the study of host microbial relationships. Bacteriological Reviews, 35(4), 390 $429 . \quad$ Retrieved from http://www.ncbi.nlm.nih.gov/pmc/articles/PMC37840 $\underline{8 /}$

[35]. Guillard, R. R. L. (1959). Further Evidence of the Destruction of Bivalve Larvae by Bacteria. The Biological Bulletin, 117(2), 258-266. Retrieved from http://www.biolbull.org/content/117/2/258

[36]. Kesarcodi-Watson, A., Kaspar, H., Lategan, M. J., and Gibson, L. (2009). Two pathogens of Greenshell ${ }^{\mathrm{TM}}$ mussel larvae, Perna canaliculus: Vibrio splendidus and a $V$. coralliilyticus/neptunius-like isolate. Journal of Fish Diseases, 32(6), 499-507. doi:10.1111/j.1365-2761.2009.01006.x

[37]. Lambert, C., Nicolas, J. L., Cilia, V., and Corre, S. (1998). Vibrio pectenicida sp. nov., a pathogen of scallop (Pecten maximus) larvae. International journal of systematic bacteriology, 48 Pt 2, 481-487.

[38]. Langdon, C. J. (1983). Growth Studies with BacteriaFree Oyster (Crassostrea gigas) Larvae Fed on SemiDefined Artificial Diets. The Biological Bulletin, 164(2), 227-235. Retrieved from http://www.biolbull.org/content/164/2/227

[39]. Le Deuff, R. M., Nicolas, J. L., Renault, T., and Cochennec, N. (1994). Experimental transmission of a Herpes-like virus to axenic larvae of Pacific oyster, Crassostrea gigas. Bulletin of The European Association Of Fish Pathologists, 14(2), 69-72. Retrieved

from http://archimer.ifremer.fr/doc/00000/2887/

[40]. Li, C.-H., Zhao, J.-M., and Song, L.-S. (2009). A review of advances in research on marine molluscan antimicrobial peptides and their potential application in aquaculture . Molluscan Research, 29(1), 17-26. 
[41]. Macey, B. M., and Coyne, V. E. (2006). Colonization of the Gastrointestinal Tract of the Farmed South African Abalone Haliotis midae by the Probionts Vibrio midae SY9, Cryptococcus sp. SS1, and Debaryomyces hansenii AY1. Marine Biotechnology, 8(3), 246-259. doi:10.1007/s10126005-0113-9

[42]. Manahan, D. T. (1989). Amino acid fluxes to and from seawater in axenic veliger larvae of the bivalve (Crassostrea gigas). Marine Ecology-progress Series - MAR ECOL-PROGR SER, 53, 247-255. doi: 10.3354/meps053247

[43]. Marques, A., Dhont, J., Sorgeloos, P., and Bossier, P. (2006a). Immunostimulatory nature of $\beta$-glucans and baker's yeast in gnotobiotic Artemia challenge tests. Fish and Shellfish Immunology, 20(5), 682-692. doi:10.1016/j.fsi.2005.08.008

[44]. Marques, A., Dinh, T., Ioakeimidis, C., Huys, G., Swings, J., Verstraete, W., and Bossier, P. (2005b). Effects of bacteria on Artemia franciscana cultured in different gnotobiotic environments. Applied and environmental microbiology,71(8), 4307-4317. doi:10.1128/AEM.71.8.4307-4317.2005

[45]. Marques, A., François, J.-M., Dhont, J., Bossier, P., and Sorgeloos, P. (2004). Influence of yeast quality on performance of gnotobiotically grown Artemia. Journal of Experimental Marine Biology and Ecology, 310(2), 247-264. doi:10.1016/j.jembe.2004.04.009

[46]. Marques, A., Ollevier, F., Verstraete, W., Sorgeloos, P., and Bossier, P. (2005a). Gnotobiotically grown aquatic animals: opportunities to investigate hostmicrobe interactions. Journal of applied microbiology, 100(5), 903-918. doi:10.1111/j.13652672.2006.02961.x

[47]. Marques, A., Thanh, T., Sorgeloos, P., and Bossier, P. (2006b). Use of microalgae and bacteria to enhance protection of gnotobiotic Artemia against different pathogens. AQUACULTURE, 258(1-4), 116-126. Retrieved from http://hdl.handle.net/1854/LU-367250

[48]. Munro, P. D., Barbour, A., and Birkbeck, T. H. (1995). Comparison of the Growth and Survival of Larval Turbot in the Absence of Culturable Bacteria with Those in the Presence of Vibrio anguillarum, Vibrio alginolyticus, or a Marine Aeromonas sp. Applied and Environmental Microbiology, 61(12), 4425-4428. Retrieved from http://www.ncbi.nlm.nih.gov/pmc/articles/PMC13886 $\underline{61 /}$

[49]. Newell, R.I.E. and Thompson, R.J. (1984). Reduced Clearance Rates Associated with Spawning in the Mussel, Mytilus edulis L. (Bivalvia, Mytilidae). Marine Biology Letters 5(1), 21-33

[50]. Newell, R.I.E. (1989). Species profiles: life histories and environmental requirements of coastal fishes and invertebrates (North and Mid-Atlantic)-blue mussel. U.S. Fish. Wildl. Serv. Biol. Rep. 82(11. 102 ). U.S. Army Corps of Engineers, TR El-82-4. 25 pp.
[51]. Paillard, C., Le Roux, F., and Borrego, J. J. (2004). Bacterial disease in marine bivalves, a review of recent studies: Trends and evolution. Aquatic Living Resources, 17(04), 477-498. doi:10.1051/alr:200405

[52]. Pronker, A. E., Nevejan, N. M., Peene, F., Geijsen, P., and Sorgeloos, P. (2008). Hatchery broodstock conditioning of the blue mussel Mytilus edulis (Linnaeus 1758). Part I. Impact of different microalgae mixtures on broodstock performance. Aquaculture International,16(4), 297-307. doi: 10.1007/s10499-007-9143-9

[53]. Provasoli, L., and Shiraishi, K. (1959). Axenic Cultivation of the Brine Shrimp Artemia salina. Biological Bulletin,117(2), 347-355. doi: $10.2307 / 1538914$

[54]. Provasoli, L., Shiraishi, K., and Lance, J. R. (1959). Nutritional Idiosyncrasies of Artemia and Tigriopus in Monoxenic Culture*. Annals of the New York Academy of Sciences, 77(2), 250-261. doi:10.1111/j.1749-6632.1959.tb36905.x

[55]. Rawls, J. F., Samuel, B. S., and Gordon, J. I. (2004). Gnotobiotic zebrafish reveal evolutionarily conserved responses to the gut microbiota. Proceedings of the National Academy of Sciences of the United States of America, 101(13), 4596-4601. doi:10.1073/pnas.0400706101

[56]. Rekecki, A., Dierckens, K., Laureau, S., Boon, N., Bossier, P., and Van den Broeck, W. (2009). Effect of germ-free rearing environment on gut development of larval sea bass (Dicentrarchus labrax L.). Aquaculture,293(1-2), doi:10.1016/j.aquaculture.2009.04.001

[57]. Reyniers, J. A. (1932). The Use of Germ-Free Guinea Pigs in Bacteriology. Proceedings of the Indiana Academy of Science,42(0), 35-36. Retrieved from https://journals.iupui.edu/index.php/ias/article/vi ew/4464

[58]. Robert, R., Miner, P., and Nicolas, J. L. (1996). Mortality control of scallop larvae in the hatchery. Aquaculture International, 4(4), 305-313. doi:10.1007/BF00120947

[59]. Salvesen, I., and Vadstein, O. (1995). Surface disinfection of eggs from marine fish: evaluation of four chemicals. Aquaculture International,3(3), 155171. doi:10.1007/BF00118098

[60]. Sedlacek, R. S., and Mason, K. A. (1977). A simple and inexpensive method for maintaining a defined flora mouse colony. Laboratory animal science, 27(5 Pt 1), 667-670.

[61]. Seed, R. (1976). Ecology. p13-65 in Bayne, B.L., ed. Marine mussels: their ecology and physiology. Cambridge University Press, New York.

[62]. Shaw, E. (1957). Potentially Simple Technique for Rearing "Germ-Free" Fish. Science, 125(3255), 987988. doi: $10.1126 /$ science. 125.3255 .987

[63]. Thompson, R. J. (1979). Fecundity and Reproductive Effort in the Blue Mussel (Mytilus edulis L.), the Sea Urchin (Strongylocentrotus droebachiensis), and the Snow Crab (Chionoecetes opilio) from Populations in Nova Scotia and Newfoundland. Journal of the 
Fisheries Research Board of Canada, 36(8), 955-964. doi:10.1139/f79-133

[64]. Tinh, N. T. N., Nguyen Ngoc Phuoc, Dierckens, K., Sorgeloos, P., and Bossier, P. (2006). Gnotobiotically grown rotifer Brachionus plicatilis sensu strictu as a tool for evaluation of microbial functions and nutritional value of different food types. Aquaculture, 253(1-4), 421-432. doi:10.1016/j.aquaculture.2005.09.006

[65]. Trexler P.C., and Orcutt R. P. (1999). Development of Gnotobiotics and Contamination Control in Laboratory Animal Science, 16:121-127.

[66]. Trust, T. J. (1974). Sterility of Salmonid Roe and Practicality of Hatching Gnotobiotic Salmonid Fish. Applied Microbiology, 28(3), 340-341. Retrieved from http://aem.asm.org/content/28/3/340

[67]. Tubiash, H. S., Chanley, P. E., and Leifson, E. (1965). Bacillary Necrosis, a Disease of Larval and Juvenile Bivalve Mollusks I. Etiology and Epizootiology. Journal of Bacteriology, 90(4), 1036$1044 . \quad$ Retrieved from http://jb.asm.org/content/90/4/1036

[68]. Vadstein, O. (1997). The use of immunostimulation in marine larviculture: possibilities and challenges. Aquaculture,155(1-4), 401-417. doi:10.1016/S0044-8486(97)00114-2

[69]. Van De Braak, K., Decamp, O., and Lavens, P. (2004). Integrated Health Management Combines Hygiene, Targeted Treatments in Shrimp Hatcheries. Global Aquaculture Advocate, 82-84. Retrieved from http://pdf.gaalliance.org/pdf/GAABraak-Oct04.pdf

[70]. Verner-Jeffreys, D. W., Shields, R. J., and Birkbeck, T. H. (2003). Bacterial influences on Atlantic halibut Hippoglossus hippoglossus yolk-sac larval survival and start-feed response. Diseases of aquatic organisms, 56(2), 105-113. doi:10.3354/dao056105

[71]. Wehrli, W. (1983). Rifampin: mechanisms of action and resistance. Reviews of infectious diseases, 5 Suppl 3 , S407-411.

[72]. Widdows, J. (1991). Physiological ecology of mussel larvae. Aquaculture, $\quad 94(2-3), \quad$ 147-163. doi:10.1016/0044-8486(91)90115-N

[73]. Yanong, R. P. E. (2013, June 25). Use of Hydrogen Peroxide in Finfish Aquaculture. Retrieved from $\underline{\text { http://edis.ifas.ufl.edu/fa157 }}$ 